\title{
Bimbingan Belajar Matematika Kepada Siswa Kelas IX Di SMP Kristen Payeti, Waingapu, Sumba Timur, NTT
}

\author{
Alfa Teni Hawu ${ }^{1}$,Feliani Absasce Markus ${ }^{2}$, Sepriati Venisia Laura Leo ${ }^{3}$ \\ ,Ferdinans Umbu Pati Ndamung ${ }^{4}$, Desi Gracelita Mutia Leo ${ }^{5}$, Jefriyanto Leba \\ Doko $^{6}$, Satrio Saputra Cornelis ${ }^{7}$, Cristovorus Mori Uma Sapulete Awa ${ }^{8}$
}
${ }^{1,2}$ Universitas Kristen Wira Wacana Sumba; Jln. R Suprapto No. 35 Waingapu, telp: 123456789, fax: 123456789
3,4,5,6,7,8 Program Studi Pendidikan Matematika, Universitas Kristen Wira Wacan Sumba e-mail: gamma.pmt@gmail.com

Informasi Artikel
Diterima Redaksi: 29 April 2019
Revisi Akhir: -
Diterbitkan Online: 6 Mei 2019
Kata Kunci
Bimbingan Belajar, Matematika, Ujian
Nasional.

Korespondensi

No. HP: 0822-6622-9120

\section{Abstract}

Learning tutoring activities for class IX students at SMP Kristen Payeti are a form of community service carried out by Gerakan Mahasiswa Matematika (Gamma) in this case to improve student learning motivation and help teachers guide class IX students to prepare themselves before National exam. The purpose of this activity is seen from the situation analysis conducted that the Mathematics learning process in the class is still not optimal due to several factors such as insufficient time to discuss too many math questions with different levels of difficulty, coupled with the number of students in the class IX which is quite a lot and has minimal teaching staff. This tutoring activity took place very well with a positive response from some students who were very enthusiastic in learning because the learning methods carried out by some counselors were very interesting but the infrastructure in schools was still very minimal so that students' learning motivation was not fully optimal. Tutoring activities as a form of community service are very important to help increase student learning motivation both in class or outside the classroom, and also as a guide is very useful as a form of new experience and closer to the community in this case the school community. 


\section{PENDAHULUAN}

Ujian Nasional (UN) dan Ujian Sekolah Berstandar Nasional (USBN) bukan lagi hal yang baru bagi Dunia Pendidikan di Indonesia [Hidayah, 2013]. Dalam perkembangan pendidikan sejak tahun 1945 sampai sekarang tahun 2019 terjadi pembaharuan yang dilakukan secara terus menerus dalam sistem Ujian terutama dalam Ujian Nasional (UN) dan Ujian Sekolah Berstandar Nasional (USBN). Hal serupa terjadi dalam kegiatan pembelajaran di kelas yang dilakukan oleh pendidik untuk meningkatkan pengetahuan siswa, pendidik memilih bimbingan belajar sebagai salah satu strategi dalam meningkatkan pengetahuan siswa. Bimbingan belajar adalah fasilitas yang dapat mengatasi kesulitan belajar yang diberikan oleh guru untuk mengembangkan suasana belajar yang kondusif dan menumbuhkan kemampuan siswa dari kesulitan belajar sehingga mencapai hasil belajar yang optimal [Aisyah, 2015]

Berdasarkan hasil Observasi dan wawancara dengan salah seorang Guru Matematika di SMP Kristen Waingapu pada tanggal 7 November 2018, diperoleh informasi bahwa pelajaran matematika masih menjadi mata pelajaran yang dianggap sulit oleh siswa kelas IX yang akan menghadapi ujian. Beliau memandang perlu adanya peningkatkan motivasi belajar siswa terhadap matematika dan bantuan pembimbing agar siswa dapat dijangkau dengan baik dan tentunya juga dapat menolong para guru untuk mempersiapkan siswa-siswi mereka menghadapi Ujian Nasional dan Ujian Sekolah dengan baik.

Sebagai tolak ukur kemampuan peserta didik, Ujian Nasional sangat berperan penting dalam hal tersebut [Ardiansyah, dkk: 2017]

Ujian Nasional juga merupakan suatu penilaian yang dirancang oleh pemerintah dan berfungsi untuk menilai pencapaian kompetensi lulusan yang telah ditetapkan pada mata pelajaran dalam suatu sistem pendidikan secara nasional. Dengan melihat hal tersebut, sehingga Ujian Nasional juga bisa disebut sistem evaluasi pembelajaran yang dilakukan di Indonesia pada jenjang sekolah dasar dan sekolah menengah, serta merupakan sebuah serana yang digunakan untuk pemetaan atau mengetahui perkembangan dari setiap daerah yang berada di wilayah Indonesia [Nursyam, 2017].

Melihat hal Itu, Himpunan MahasiswaPendidikan Matematika (GAMMA) memandang perlu untuk 
melaksanakan suatu kegiatan pengabdian kepada masyarakat yang mampu meningkatkan motivasi belajar siswa dan membantu Guru-guru untuk membimbing siswa-siswi mereka, sehingga dapat mendukung dan mempersiapkan siswa-siswi kelas IX di SMP Kristen Waingapu untuk menghadapi ujian yang dalam waktu dekat yang akan diselenggarakan di Seluruh Indonesia.

\section{METODE}

Kegiatan ini diadakan di SMP Kristen Payeti,pada tanggal 4 februari 2019 -12 april 2019 dan ditutup pada tanggal 13 april 2019. Sasaran untuk tercapainya tujuan dari kegiatan ini adalah siswa kelas IX yang akan menghadapi Ujian Nasional dan Ujian Sekolah. Sehingga, Untuk merealisasikan tujuan tersebut Gamma Unkriswina Sumba melaksanakan bimbingan belajar untuk siswa kelas IX di SMP Kristen Payeti.

\section{HASIL DAN PEMBAHASAN}

Jadwal kegiatan dirinci dalam kurun waktu 2 (dua) bulan, dimana tiap minggunya diadakan 2 (dua) kali pertemuan dengan waktu 2 jam dalam sekali pertemuannya. Kegiatan ini dilaksanakan dengan pemberian materi, membahas soal-soal Nasional tiga tahun terakhir dan pembahasan soal try out oleh mahasiswa pendidikan matematika
Unkriswina Sumba. Yang menjadi kendala dalam proses pelaksanaan kegiatan ini adalah kurangnya sarana prasarana pendukung pembelajaran yang ada di sekolah dan masih banyak siswa yang tidak ikut berpartisipasi dalam proses bimbingan. Namun, ada pengakuan secara pribadi dari salah satu seorang guru yang mengampuh mata pelajaran Matematika di SMP Kristen Payeti bahwa, dengan adanya kegiatan bimbingan belajar ini, ada sedikit perubahan yang nampak dari hasil Try Out ke-2 dan ke-3, dimana pada hasil Try Out ke-3 ada beberapa siswa yang nilainya sedikit meningkat dibandingkan dengan hasil sebelumnya.

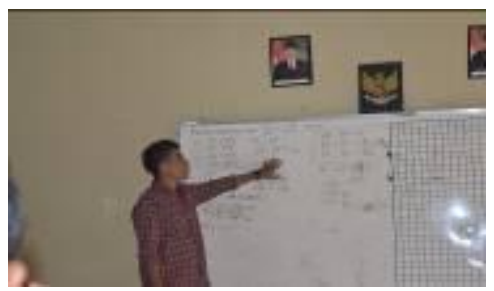

Gambar 1. Pembahasan soal try out

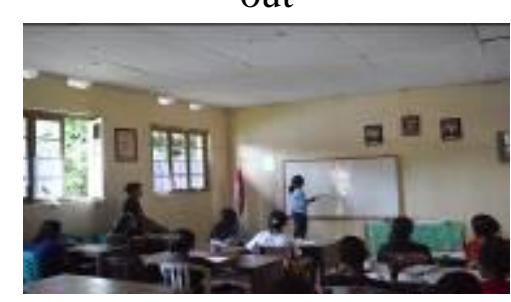

Gambar 2. Pemberian materi oleh mahasiswa

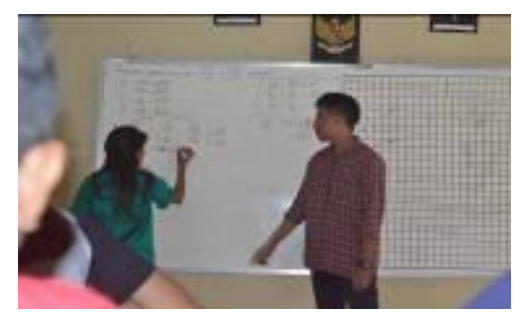

Gambar 3. Siswa mengerjakan soal yang diberikan. 
Penutupan kegiatan ini dilaksanakan pada tanggal 13 april 2019, yang dihadiri oleh ketua program studi pendidikan matematika, Bapak Erwin Randjawali S,Pd,. M.Si., beberapa guru di SMP Kristen Payeti dan juga beberapa Siswa-siswi yang sempat hadir pada saat itu

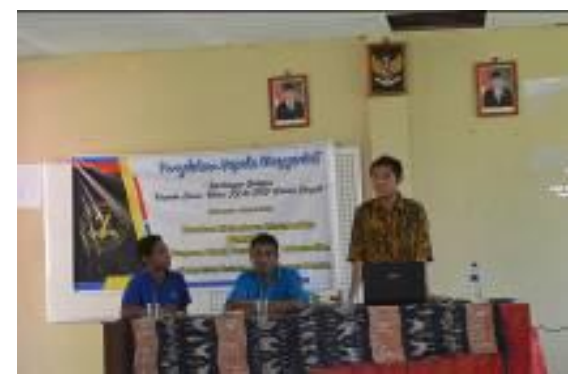

Gambar 4. Sambutan dari ketua program studi pendidikan matematika

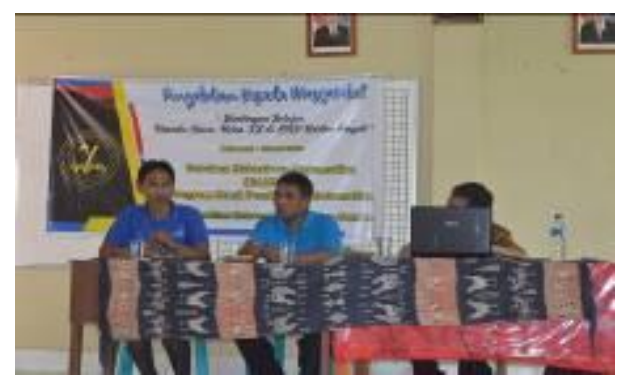

Gambar 5. Perwakilan sekolah menutup kegiatan

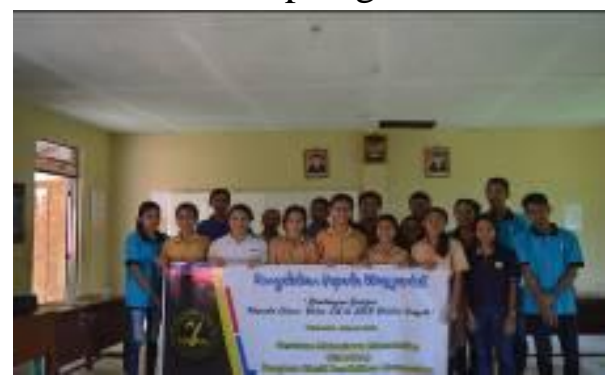

Gambar 6. Foto bersama panitia dan peserta

\section{KESIMPULAN}

Kegiatan pengabdian ini diadakan dengan memberikan bimbingan belajar kepada siswa kelas IX selama dua bulan dan dalam proses bimbingan selama dua bulan tersebut banyak Siswa-siswa terlihat semangat dan antusias dalam menerima pembelajaran, akan tetapi proses pembelajaran di sekolah tersebut tidak didukung dengan Sarana prasarana pendukung memadai sehingga motivasi belajar dari siswa itu sendiri masih sangat kurang.

\section{SARAN}

Adapun saran dari penulis bahwa suatu kegiatan belajar-mengajar tidak akan berjalan dengan maksimal jika tidak didukung dengan sarana-prasarana yang menunjang proses pembelajaran itu sendiri, sehingga menjadi tugas terbesar yang harus diperhatikan pemerintah dan pihak sekolah untuk tidak menganggap remeh sarana-prasarana yang sebenarnya harus disediakan.

Selain itu untuk siswa dan guru sendiri, dalam proses belajar-mengjara tidak hanya di sekolah karena umumnya pembelajaran matematika sangat berkesinambungan dengan kehidupan sehari-hari.

Bagi pembimbing, diharapkan untuk kegiatan pengabdian berikutnya untuk melakukan persiapan yang lebih baik.

\section{UCAPAN TERIMA KASIH}

Ucapan terima kasih kepada Ketua Program Studi Matematika dan juga Dekan Fakultas Ilmu-Ilmu Sosial yang telah menyetujui kegiatan bimbingan 
belajar ini sebagi bentuk pengabdian kepada masyarakat. Terima kasih juga kepada pihak sekolah SMP Kristen Payeti yang telah menerima dan mempercayai kami untuk melakukan kegiatan bimbingan belajar ini. Ucapan terima kasih yang berikutnya kepada teman-teman mahasiswa yang sudah boleh meluangkan waktu untuk kegiatan bimbingan belajar ini.

\section{DAFTAR PUSTAKA}

[1] Aisyah, S. 2015. Perkembangan Peserta Didik dan Bimbingan Belajar.Yogyakarta Deepublihs.
[2] Ardiansyah, dkk. 2017. Tinggakt Kecemasan Siswa Dalam Mengahadapi Ujian Nasional Berbasis Komputer (UNBK) di SMK Al Munawwariyyah Bululawang. Vol:2. No. 2. Hal. 44

[3] Hidayah, N. 2013. Ujian Nasional Dalam Perspektif Kebijakan Publik. Vol:7. No. 1. Hal. 35-40

[4] Nursyam. 2017. Efektivitas Pelaksanaan Unjian Nasional Tingkat Sekolah Menengah Atas Negeri Oleh Dinas Pendidikan Dan Pengajaran Kota Palu Provinsi Sulawesi Tengah. Vol:5. No.1. Hal. 11-12 